\title{
Depriving the Debtor's Essential Obligation of its Substance and its Remedies under the Provisions of Article 1170 of the French Civil Code
}

\author{
Yousef Mohammad Shandi ${ }^{1} \&$ Osama Ismail Mohammad Amayreh ${ }^{2}$ \\ ${ }^{1}$ Faculty of Law, Arab American University, Palestine \\ ${ }^{2}$ Faculty of Law, University of Malaya, Malaysia \\ Correspondence: Osama Ismail Mohammad Amayreh, Faculty of Law, University of Malaya, Malaysia. E-mail: \\ adv-osama@outlook.com
}

Received: February 21, 2020

Accepted: April 2, 2020

Online Published: May 25, 2020

doi:10.5539/jpl.v13n2p129

URL: https://doi.org/10.5539/jpl.v13n2p129

\begin{abstract}
In 1994 and thereafter, the French judiciary set a trend by utilizing the causation theory to revoke the exemption clauses of liability that constitute a violation of the contract's essential obligations. This utilization was intended to restore economic equilibrium to the contract, in order to achieve the benefit each party seeks from concluding a contract. However, in 2016, the new amendments of the French civil code -which were issued by decree no: 131-2016- abolished the causation theory in general. Nevertheless, they retained the previous French judicial trend based on causation theory, where Article 1170 of the new amendments states clearly "any contract term which deprives a debtor's essential obligation of its substance is deemed not written". However, Article 1170 of the new amendments did not specify what is meant by an essential obligation? When does the contract's term result in depriving the debtor's essential obligation of its substance? Moreover, Article 1170 consolidates an individual penalty which may cause many legal problems. These problems are: the matter concerns an essential clause in the contract and not a secondary one, the other clauses of the contract remain valid as they have been, without any modifications or replacements and, in some cases, abolishing the clause itself might lead to further imbalance in the contract. Therefore, the legal provisions of Article 1170 should be analyzed in an analytical approach along with the previous French judicial trend with respect to these provisions. As a result, the research illustrates the urgent need to amend Article 1170 of the new amendments, in order to contribute to the stability of the economic contractual equilibrium.
\end{abstract}

Keywords: essential obligation, contractual terms, economic contractual equilibrium, Chronopost's decision, Faurecia's decision, New French Civil Code

\section{Introduction}

Article 1170 of the French Civil Code which was amended by Decree No 131-2016 on the 10th of February 2016 (NFCC) ${ }^{1}$ stipulates that: "any contract term which deprives a debtor's essential obligation of its substance is deemed not written". ${ }^{2}$ Indeed, this article is a codification of the case law of the French Court of Cassation which was based on the causation theory (as contained in Article 1131 of the French Civil Code of 1804) to restore contractual equilibrium by annulling any contract term which deprives a debtor's essential obligation of its substance. ${ }^{3}$ However, the utilization of causation theory was aimed to prevent the arbitrary terms in contracts generally depending on the general rules of contract theory. ${ }^{4}$ This is true, particularly, in case of some

\footnotetext{
${ }^{1}$ (Hereinafter 'NFCC'), however, this Article was inserted by the French Decree No. 131-2016 on 10/02/2016, which was enacted by the ratification decree No. 287-2018 on 20/04/2018.

${ }^{2}$ The original text in French is "Toute clause qui prive de sa substance l'obligation essentielle du débiteur est réputée non écrite".

${ }^{3}$ See Le Coq, J. (2017). The Stakes and Objectives of the Reform of Contract Law, General Regime and Proof of Obligations. International Business Law Journal, 2017(6), p 530. Pop, L. (2018). General Considerations on the Reform of the Right of Obligations in the French Civil Code. Romanian Review of Private Law, 2018(1), p 288. Alexe, A. (2017). Clauses Deemed Unwritten. International Landmarks. Research and Science Today, 13(Supplement 1), p 24-25. Schmidt, J. (2002). Les Lettres D'intention. International Business Law Journal, 2002(Issues \& 4), p 261. Blanc-Jouvan, X. (2009). Towards the Reform of the Law of Obligations in France: The Reasons for the Reform. Tulane Law Review, 83(4), p 860.

${ }^{4}$ See Asfar-Cazenave, C. (2015). The New French Contract Law. Revue Juridique Themis, 49(3), p 737.
} 
contractual terms leading to a significant imbalance between the corresponding obligations, ${ }^{5}$ and where these terms cannot be revoked under the rules of consumer protection against arbitrary terms. Consequently, these arbitrary terms were considered unwritten, if they deprive the debtor's essential obligation of its substance. ${ }^{6}$ In this context, the French jurist Viney stated that: "the French Court of Cassation's use of the causation theory was only an attempt to establish a legal basis which allows it to revoke arbitrary terms"?

As such, most French jurists support the new text (Article 1170) in spite of the present difficulties in its application. ${ }^{8}$ However, nevertheless, other jurists criticise it severely, on the basis that the French court of cassation's case law was aimed at extending the legal protection against arbitrary terms to include professionals who were excluded from the scope of consumer protection law $;{ }^{9}$ however, as long as the NFCC provides the intended protection to professionals from arbitrary terms in contracts of adhesion under Article $1171,{ }^{10}$ there is no need for enacting Article 1170 of the NFCC.

In response to these criticisms, the scope of application of Article 1170 appears to be completely different, as Article 1170 did not even use the phrase "arbitrary terms", which was in order to ensure that this provision applies only to contract terms that deprive the debtor's essential obligation of its substance, and not as a means of preventing arbitrary terms in contracts generally, including contracts of adhesion.

In fact, Article 1170 of the NFCC establishes a theory similar to the theory of Fundamental Breach, used in English law, which states that in case the debtor refrains from performing his essential contractual obligations, then he shall be deprived of invoking the exemption clause or limiting liability clause. ${ }^{11}$ Likewise, Article 1170 of the NFCC is largely in accordance with Article 7.1.6 of the UNIDROIT Principles of International Commercial Contracts (PICC) of $2016^{12}$ which states: "a clause which limits or excludes one party's liability for non-performance or which permits one party to render performance substantially different from what the other party reasonably expected may not be invoked if it would be grossly unfair to do so, having regard to the purpose of the contract". ${ }^{13}$ Meanwhile, Article 8: 109 of the Principles of European Contract Law (PECL) ${ }^{14}$ clearly prevents invoking the exemption clauses of liability in certain cases. ${ }^{15}$

However, Article 1170 of the NFCC, along with the previous French case law, constitutes a restriction on the freedom of contracting, and on the principle of the binding force of contracts, as it allows the judge to revoke

\footnotetext{
${ }^{5}$ See Fokou, E. (2016). La Notion d'Economie du Contrat en Droit Francais et Quebecois. Revue Generale de Droit, 46(2), p 373.

${ }^{6}$ Chénedé, F. (2016). Le nouveau droit des obligations et des contrats: consolidations, innovations, perspectives. Paris, France: Dalloz. P 98.

${ }^{7}$ G. Viney, "La clause dite "de réclamation de la victime" en assurance de responsabilité", JCP 1994, I, 3778, no 20 : « qu'un habillage juridique, la raison profonde de la condamnation était en réalité le caractère abusif de la clause et des pratiques auxquelles elle peut donner lieu ».

${ }^{8}$ See Rowan, S. (2017). The New French Law of Contract. International and Comparative Law Quarterly, 66(4), p 818-819. Pillet, G. (2016). The Reform of French Contract Law and of the General Rules on Obligations: The Civil Code Faces the Challenges of the Market. International Business Law Journal, 2016(3), p 246-252. Mekki, M. (2017). The French Reform of Contract Law: The Art of Redoing Without Undoing. Journal of Civil Law Studies, 10(1), p 241.

${ }^{9}$ Chénedé, F. (2016). Le nouveau droit des obligations et des contrats: consolidations, innovations, perspectives. Supra note, p 99. Mekki, M. (2017). The French Reform of Contract Law: The Art of Redoing Without Undoing. Supra note, p 243.

${ }^{10}$ Article 1171 of the NFCC states: "1- any term of a standard form contract which creates a significant imbalance in the rights and obligations of the parties to the contract is deemed not written. 2- the assessment of significant imbalance must not concern either the main subject matter of the contract or the adequacy of the price in relation to the act of performance".

${ }^{11}$ Borello, M. (1984). Conformité, Garantie et Clauses élisives ou Limitatives de Responsabilité dans le Droit Anglais de la Vente. Revue internationale de droit comparé, 36(2), p 373-380. However, there is a new standard under UK's law which considers the exemption clause of liability void if the failure to perform resulted in bodily harm, or if the condition was unconscionable. See Alexe, A. (2017). Clauses Deemed Unwritten. Supra note, p 27. Woker, T. (1999). The Right of an Employer to Exempt Himself or Herself from Liability for the Deliberate Wrongs of His or Her Employee. South African Law Journal, 116(4), p 725-726.

12 (Hereinafter 'PICC').

13 "Une partie ne peut se prévaloir d'une clause limitative ou exclusive de responsabilité en cas d'inexécution d'une obligation, ou lui permettant de fournir une prestation substantiellement différente de celle à laquelle peut raisonnablement s'attendre l'autre partie, si, eu égard au but du contrat, il serait manifestement inéquitable de le faire". Nevertheless, it is stated in the official explanation of Article 7.1.6 of the PICC that "the reason for the inclusion of a specific provision on exemption clauses is that they are particularly common in international contract practice and tend to give rise to much controversy between the parties". Whereas the exemption clauses of liability in the United Nations Convention on Contracts for the International Sales of Goods (CISG) are governed by the applicable national law under Article 4 of the CISG. See Rawach, E. (2001). La Validité des Clauses Exonératoires de Responsabilité et la Convention de Vienne sur la Vente Internationale de Marchandises. Revue internationale de droit comparé, 53(1), 141-157.

14 (Hereinafter 'PECL').

15 "Remedies for non-performance may be excluded or restricted unless it would be contrary to good faith and fair dealing to invoke exclusion or restriction".
} 
some of the contractual terms, and consider them as unwritten, if they deprived the debtor's essential obligation of its substance. ${ }^{16}$ Therefore, Article 1170 of the new amendments raised many questions, such as the following: What is the scope of the application of this article? What is meant by an essential obligation? When does the contract's term result in depriving the debtor's essential obligation of its substance? How is the penalty contained in Article 1170 applied? These and other questions will be answered in this paper. To this end, the legal provisions of Article 1170 should be analysed in an analytical approach along with the French judicial trend and the juristic views on these provisions. This requires us to study the scope of the application of this article and the legal terms for this article's application and the resulting penalty.

\section{Scope of Application of Article 1170}

The determination of the scope of application of Article 1170 of the NFCC necessitates an understanding of the context in which this article was codified. This, therefore, requires us to, first, review the most influential case law of the French Court of Cassation in this regard, which was a source of inspiration for enacting Article 1170 of the NFCC, and then we will address the extent of enforcement of Article 1170.

\subsection{The Facts of Chronopost Decision}

As stated earlier, Article 1170 of the NFCC is considered a codification of the French Court of Cassation's judicial approach in the Chronopost case, which was based on causation theory contained in Article 1131 of the French Civil Code of 1804. ${ }^{17}$ The Commercial Room of the French Court of Cassation considered the exemption clauses of liability which determined the amount of compensation in case of the debtor's failure to perform his obligation as unwritten. ${ }^{18}$

The facts of this case are abbreviated in the following: Banchereau company has submitted a postal parcel (containing Banchereau's participation in a tender for the supply of meat) to the Chronopost Expressway Company, along with an extra fee for delivering the postal parcels containing Banchereau's participation within a specified time. However, the postal parcels arrived later than the specified time. Banchereau, then, filed a lawsuit against Chronopost, demanding compensation for the damages it suffered. However, Chronopost company relied on the limitation of its liability clause, stated in the contract -which determines the liability of the Chronopost company, in the event of breaching its performance, by paying the same amount paid by the customer. In this regard, the Rennes Court of Appeal ruled in favour of Chronopost, based on the limitation clause of liability. ${ }^{19}$

However, on the $22^{\text {nd }}$ of October 1996, the French Court of Cassation rescinded the decision of the Rennes Court of Appeal and ruled that: whereas in so doing, the Chronopost Expressway Company, considered as being

\footnotetext{
${ }^{16}$ See Faria, J. (2016). The Influence of the Unidroit Principles of International Commercial Contracts on National Laws. Uniform Law Review, 2l(2-3), p 265-266.

${ }^{17}$ Article 1131 of the French Civil Code of 1804 states: "an obligation without a cause, or upon a false cause, or upon an unlawful cause, can have no effect".

${ }^{18}$ Com. 22 oct. 1996, n 93-18632, Bull. civ. IV, nº 261 ; D. 1997, 121, note A. Sériaux ; Defrénois 1997, 333, obs. D. Mazeaud ; JCP E 1997, II, 924, note K. Adom ; LPA 18 juin 1997, p. 30, note D. R. Martin ; D. 1997, 145, chron. C. Larroumet ; D. 1997, 175, obs. P. Delebecque ; CCC Fevr. 1997, p. 9, obs. L. Leveneur ; RTD civ. 1997, 418, obs. J. Mestre ; RTD civ. 1998, 213, obs. N. Molfessis ; RTD

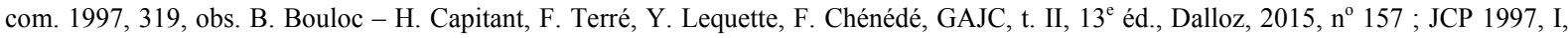
4002, n 1, obs. Fabre-Magnan ; JCP 1997, I, 4025, obs. G. Viney ; Dr. et patr. 1997, 63, note P. Chauvel ; JCP 1997, II, 22881, note D. Cohen ; Ph. Delebecque, "Que rest-t-il du Principe de validité des clauses de responsabilité ? », D. Affaires 1997, 235 ; J.-P. Chazal, " théorie de la cause et justice contractuelle : a propos de l'arrêt Chronopost (Com. 22 oct. 1996), JCP 1998, I, 152. See also Ghozlan, S. (2015). The Concept of Essential Obligation Under the Control of Abusive Clauses: The Study of French and Quebec Legal Systems. Revue Juridique Themis, 49(2), p 411. Valentino, D. (2016). Software Assistance and Maintenance Contracts. European Business Law Review, 27(4), p 552. Mato Pacin, M. (2015). Content Control of Standard Terms in Business-to-Business Contracts in Comparative and European Law. Cuadernos de Derecho Transnacional, 7(2), p 224-225. Chappuis, C. (2008). Le Renoncement la Cause et la Consideration dans l'avant-Projet d'acte Unifrome Ohada sur le Droit des Contrats. Uniform Law Review, 13(Issues and 2), p 267-268.
}

Prior to this case, the French court of cassation used the causation theory to annul some sort of contractual terms, such as, firstly, the commercial room of French court of cassation abolish the terms called "Dates de valeurs" since they gave an unjustified advantage for the financial institution. See Com. 6 avr. 1993. no 90-21198, Bull. civ. IV, n 138; D. 1993, 310, note C. Gavalda; RTD com. 1993, 549, obs. B. Teyssié et M. Cabrillac.

Secondly, the Civil Room 1 of the French Court of Cassation abolish a term called "Couperet ou réclamation victim", as it excludes the insurer's guarantee of the accident, which occurred during the validity of the insurance contract. See Civ. $1^{\text {re }}, 19$ déc. 1990, $\mathrm{n}^{\circ}$ 88-12863, Bull. Civ. I, n 303; RDI 1991, 78, obs. G. Leguay et P. Dubois; RTD civ. 1991, 325, obs. J. Mestre; JCP 1991, II, 21656, note Bigot.

However, subsequent to Chronopost case, the French Court of Cassation used the causation theory to annul some sort of contractual terms. See: Civ. ${ }^{\text {re }}, 16$ déc. 1997, $n^{\circ}$ 94-17061 et no 94-20060 : Bull. civ. I, nº 370 ; D. 1998, 287, note Y. Lambert-Faivre ; JCP 1998, II, 10018, rapp. P. Sargos.

Civ. 3e, 26 nov. 2015, n 14-25761; Gaz. Pal. 2016, n 3. P. 28, obs. N. Blanc ; D. 2016, 458, note R. Boffa ; D. 2016, 571, obs. M. Mekki.

${ }^{19}$ See (2017). Limitation and Exclusion clauses in CISG Contracts. Nordic Journal of Commercial Law, 2017(2), p 282. 
specialized in fast transportation and should thus guarantee the accuracy and speediness of its services, had pledged to deliver the postal parcels containing Banchereau's participation within a specified time, and failed to perform its essential obligation; then, the limiting clause of liability of the Chronopost company contradicted the effect of the pledge given and, thus, had to be considered as unwritten, and had to be deemed null and void. ${ }^{20}$

In this case, the French Court of Cassation relied on the following legal rationale: the debtor is depriving its essential obligation of its substance in case of the debtor limit or exempt its liability in the event of a breach of its contractual obligations. Subsequently, Chronopost's essential obligation was not only to deliver the postal parcels, but was also to deliver them at the agreed time specified in the contract, because it is a matter of rapid transportation. Otherwise, Banchereau would not have accepted a higher payment than it could have paid for delivering the postal parcels using the normal post. Thus, Chronopost Company has breached this essential obligation (not delivering the postal parcels on the agreed date specified in the contract) which represents the essence of this contract, where also the interest or the utility that Banchereau company was waiting to achieve from paying a price to Chronopost company was wasted. And since the delivery was made later than the agreed date, part of Chronopost's obligation would be absent, namely: delivering the postal parcels on the agreed date specified in the contract (which was not done). This situation is called the partial absence of the cause of the obligation. ${ }^{21}$

\subsection{The Facts of Faurecia II Decision}

Despite the fact that most French jurisprudence supported the French judicial approach in the Chronopost case in terms of its outcome; nonetheless, it expressed concern about this decision, in terms of generalizing the application of this penalty to all limiting or exemption clauses of liability as long as these clauses infringe on the debtor's essential obligation. ${ }^{22}$ In other words, it expressed a fear that any limiting clause of liability will always be considered unwritten simply since it infringes on an essential obligation. These concerns were heightened by the decision of the French Court of Cassation in the case of Faurecia II, ${ }^{23}$ which put the validity of exemption and limiting clauses of liability to the test, since the decision hints that the limiting clause of liability should be excluded every time an "essential breach of obligation" is verified regardless of the amount of compensation contained in the limiting clause of liability.

However, the Commercial Room of the French Court of Cassation became aware of this issue, ${ }^{24}$ as it has ruled in the case of Faurecia II that: exemption or limiting clauses of liability are generally valid, and that only the clauses that completely deprive the debtor's essential obligation of its substance are excluded. ${ }^{25}$ Accordingly, not all of the clauses relating to non-performance of an essential obligation are nullified, but only those clauses that deprive the debtor's essential obligation of its substance.

Thus, the Commercial Room of the French Court of Cassation affirmed that for a clause to be deemed unwritten, the creditor must prove two things: First, it should be proven that the limiting or exemption clause infringes on the debtor's essential obligation. ${ }^{26}$ Second, it should be proven that this clause deprives the debtor's essential obligation of its substance. ${ }^{27}$ Nevertheless, in order to ascertain the extent to which the limiting clause of

\footnotetext{
20 “en statuant ainsi, alors que le spécialiste du transport rapide garantissant la fiabilité et la célérité de son service, la société Chronopost s'était engagée à livrer les plis de la société Branchereai dans un délai déterminé et qu'en raison du manquement à cette obligation essentielle, la clause limitative de responsabilité du contrat, qui contredisait la portée de l'engagement pris, devait être réputée non écrite".

${ }^{21}$ See Ghozlan, S. (2015). The Concept of Essential Obligation Under the Control of Abusive Clauses: The Study of French and Quebec Legal Systems. Supra note, p 411-412. Mato Pacin, M. (2015). Content Control of Standard Terms in Business-to-Business Contracts in Comparative and European Law. Supra note, p 224-225.

${ }_{22}$ Gheorghe, O. (2018). Theoretical Considerations and Practical Aspects on the Institution of Guilt within the Contractual Liability and the Limitation of the Contractual Liability. Journal of Law and Public Administration, 4(7), p 47-48.

${ }^{23}$ See Com. 13 févr. 2007, nº 05-17407, Bull. civ. IV, nº 43; D. 2007, 654, obs. X. Delpech; D. 2007, 2966, obs. S. Amrani-Mekki et B. Fauvarque-Cosson; RTD civ. 2007, 567, obs. B. Fages; JCP 2007, II, 10063, note M. Serinet.

${ }^{24}$ Com. 29 juin 2010, $\mathrm{n}^{\circ}$ 09-11841, Bull. civ. IV, $\mathrm{n}^{\circ}$ 115; JCP 2010, $\mathrm{n}^{\circ}$ 787, note D. Houtcieff; CCC 2010, comm. 220, obs. L. Leveneur; D. 2010, 1832, note D. Mazeaud; JCP 2010, nº 1015, obs. Ph. Stoffel-Munck; JCP 2011, n ${ }^{\circ}$ 63, obs. J. Ghestin; RDC 2010, 1220, obs. Y.-M. Laithier; RDC 2010, 1253, obs. O. Deshayes; RTD civ. 2010, 555, chron. B. Fages; Contrats conc. consom. 2010, $\mathrm{n}^{\circ} 220$, obs. L. Leveneur; Comm. Com. Electr. 2010, nº 99, obs. Stoffel-Munck; Rev. Lamy dr. civ. 2010/76, nº 3994, obs. Pimont; RDC 2010, 1220, obs. Y.-M. Laithier.

Ganilsy, M.; Wachtel, R. (2012). Civil Liability Under French Law and PCI DSS. International Business Law Journal, 2012(1), p 127-128. (2017). Limitation and Exclusion clauses in CISG Contracts. Supra note, p 283.

25 "seule est réputée non écrite la clause limitative de réparation qui contredit la portée de l'obligation essentielle suscrite par le débiteur".

${ }^{26}$ See Valentino, D. (2016). Software Assistance and Maintenance Contracts. Supra note, p 552-553.

${ }^{27}$ See Gheorghe, O. (2018). Theoretical Considerations and Practical Aspects on the Institution of Guilt within the Contractual Liability and the Limitation of the Contractual Liability. Supra note, p 47.
} 
liability is incompatible with the substance of the debtor's essential obligation, the overall contractual equilibrium must be reviewed in the entire contract. This necessarily requires a complete review of the contract for another element of that could lead to rebalancing this clause. For example, lowering the price in return for the limiting clause of liability prevents the clause from being deemed as unwritten. ${ }^{28}$

\subsection{The Extent of Enforcement of Article 1170}

Article 1170 of the Amended French Civil Code affirmed the French judicial trend in the previous cases (Chronopost and Faurecia II) -in particular, the case of Faurecia II, from which came the current wording of the text of Article 1170. Nonetheless, Article 1170 of the NFCC states that: "any contract term which deprives a debtor's essential obligation of its substance is deemed not written". Therefore, even though the new amendments of the French civil code -which were issued by decree no: 131-2016- abolished the causation theory in general. Nevertheless, they retained its most important modern judicial applications. ${ }^{29}$ This position was basically aimed to restore the contractual equilibrium through abolishing the clause which deprives a debtor's essential obligation of its substance.

In addition, it should be noted that the scope of application of Article 1170 is much broader than the preceding French judicial approach, as the French Court of Cassation restricted its scope of application only to the limiting and exemption clauses of liability, whereas Article 1170 includes all contract terms that deprive a debtor's essential obligation of its substance, regardless of whatever is the nature of these contract terms. Therefore, henceforth, Article 1170 can be utilized to abolish contract clauses such as: limitation or exemption clauses of liability, clauses related to force majeure, renegotiation clause, arbitration clause, non-competition clause, earnest payment clause, judicial Jurisdiction clause, clause of short-term claim, exclusivity clause, or the clause of early termination of contract, etc., i.e. all clauses the subject of which is to restrict or constrain the creditor's right to claim his right or to invoke a privilege legally granted may fall within the scope of application of this article.

Based on the above, it appears that Article 1170 is considered as an exception of the principle of contractual freedom, ${ }^{30}$ as it allows the judge in exceptional cases to abolish certain contractual clauses that are incompatible with the principle of the binding force of contracts. In contrast, Article 1170 cannot be considered as a general rule for rebalancing contracts generally by allowing the judge to revoke some of its clauses.

In spite of the obvious purpose that the French legislature seeks to achieve from enacting Article 1170, namely to restore economic contractual equilibrium to the contract, ${ }^{31}$ the legal jurisprudence, nonetheless, manifests some concern regarding the application of this article with respect to the following three aspects: first, the content of the terms used by the text is not defined and there is no clear mechanism for its application, as such: What is meant by the concept of "essential obligation"? When does the contract clause lead to deprive a debtor's essential obligation of its substance? Is the contractual equilibrium estimated by reviewing the entire contract or based on the clause itself? Could there be other clauses in the contract that would not make the clause deprive the debtor's essential obligation of its substance?; second, "the fear of moving from a mere judicial solution related to one clause -which is the exemption clause of liability- to a general provision the application of which is not limited to specific cases", ${ }^{32}$ third, concerning the scope of application of Article 1170, as some jurists believe that this article applies only to contracts of adhesion without including negotiating contracts, ${ }^{33}$ while the majority of the French jurists, which is the position we support, believe that Article 1170 applies to all contracts, whether they are contracts of adhesion or negotiation contracts. Nevertheless, it should be noted that the scope of application of Article 1170 relates only to the revocation of any contract clause which deprives a debtor's essential obligation of its substance, and does not addresses the arbitrary conditions in contracts of adhesion mentioned in Article 1171 of the NFCC.

\section{Terms of Application of Article 1170}

The application of the 1170 Article of the NFCC requires meeting two conditions which are the following: first,

\footnotetext{
${ }^{28}$ See Pillet, G. (2016). The Reform of French Contract Law and of the General Rules on Obligations: The Civil Code Faces the Challenges of the Market. Supra note, $\mathrm{p} 246$.

${ }^{29}$ Rowan, S. (2017). The New French Law of Contract. Supra note, p 818.

${ }^{30}$ See Pillet, G. (2016). The Reform of French Contract Law and of the General Rules on Obligations: The Civil Code Faces the Challenges of the Market. Supra note, p 251-252.

${ }^{31}$ See Fokou, E. (2016). La Notion d'Economie du Contrat en Droit Francais et Quebecois. Supra note, p 343-378.

${ }^{32}$ Deshayes, O., Genicon, T., \& Laithier, Y. M. (2016). Réforme du droit des contrats, du régime général et de la preuve des obligations: commentaire article par article. LexisNexis. p 293.

${ }^{33}$ Ibid., p 297.
} 
that the clause has to be related to an essential obligation of the debtor, which requires specifying the concept of "essential obligation" (the first part of the section) and, second, that this clause leads to depriving the essential obligation of the debtor of its substance (part two of the section).

\subsection{The Concept of the Essential Obligation of the Debtor}

The application of Article (1170) hinges on specifying the concept of the essential obligation of the debtor. To begin with, it is notable that Article 1170 of the NFCC did not offer any definition of this concept and, moreover, it did not allude to any indicators as regards the specification of what are considered essential obligations as to distinguish them from other types of contractual obligations, which produces a lot of real difficulties concerning the application of the text especially given the parties' expectations regarding the manner of its application. ${ }^{34}$ Hence, the core problem in specifying what is considered an "essential obligation" lies in the fact that the contract includes a lot of fundamental and secondary obligations that are interrelated, as "all of the terms of a contract can be considered part and parcel of the fundamental obligation, as they all seek to achieve the purpose behind the contract". ${ }^{35}$

Going back to the opinions of the jurisprudence and French judicial precedents both old and recent, there is a huge variation concerning what is considered an essential obligation or a fundamental one in a particular contract; for, what is considered an essential obligation in a given contract for some and in some judicial precedents may not be taken as such for some other jurists or in some other judicial precedents.

As regards the French judicial precedents, we find, for instance in contracts of electricity-supply, that the Commercial Room of the French Court of Cassation ruled that continuing the supply of electricity for a certain customer is not considered an essential obligation upon the French Electricity Company (EDF); furthermore, its discontinuation of supply is not considered a violation of an essential obligation on its behalf. ${ }^{36}$ However, the Civil Room 1 of the French Court of Cassation ruled in support of the decision of a court of Appeals in which it ruled that the French Electricity Company's discontinuation of electricity supply for one of the customers is considered an essential obligation on behalf of this company. ${ }^{37}$

This is the same approach taken by the French Court of Cassation in another case concerning supply of internet services, as it ruled that continuation of supplying internet services is considered as a fundamental part of the essential obligations of the internet provider, and that this obligation is a commitment towards achieving a purpose. ${ }^{38}$ Similarly, in the case of leasing contracts: we find that the French Court of Cassation, in an old case, considered that the essence of a leasing contract -i.e., its essential obligation- obliges the lessor to maintain the leased property for the duration of the contract's validity. ${ }^{39}$ However, in another later case, the French Court of Cassation ruled that the lessor's obligation to maintain the leased property, during the period of the contract, does not represent the essence of the contract. ${ }^{40}$

As such, part of the jurisprudence ${ }^{41}$ tries to identify what is considered an essential obligation in a given contract based on Pothier's classification, which is based on Roman Law, which distinguishes between three types of obligations: essential, natural and accidental obligations.

As regards essential obligations (Les essentialia), these are the fundamental or essential obligations that affect

\footnotetext{
${ }^{34}$ Mekki, M. (2017). The French Reform of Contract Law: The Art of Redoing Without Undoing. Supra note, p 231.

35 "toutes les clauses du contrat peuvent être considérées comme partie intégrante de l'obligation essentielle, car elles sont toutes mises au service de la pleine réalisation de l'objet de la convention". See Deshayes, O., Genicon, T., \& Laithier, Y. M. (2016). Réforme du droit des contrats, du régime général et de la preuve des obligations: commentaire article par article. Supra note, p 293.

${ }^{36}$ Com. 18 dec. 2007, nº 04-16069, Bull. civ. IV, $\mathrm{n}^{\circ}$ 265; D 2008, p. 154, note D. Mazeaud: « Clauses limitatives de réparation: les quatre raisons », RDC 2008, p. 262, obs. Th. Genicon; RDC 2008, p, 287, obs. G. Viney; JCP G 2008, I, 125, nº 13, obs. Ph. Stoffel-Munck; RTD civ. 2008,310 , obs. P. Jourdain.

${ }^{37}$ See "French Court of Cassation, civil room 1, public sitting of Tuesday 24 September 2002, no of appeal: 99-13537," légifrance, le service public de la diffusion $\mathrm{du}$ droit, accessed September 21, 2019, https://www.legifrance.gouv.fr/affichJuriJudi.do?oldAction=rechExpJuriJudi\&idTexte=JURITEXT000007441605\&fastReqId=1720391102 $\&$ fastPos $=77$.

${ }^{38}$ See "French Court of Cassation, civil room 1, public sitting of Thursday 8 November 2007, no of appeal: 05-20637," légifrance, le service $\begin{array}{llllllll}\text { public de la diffusion } \quad \mathrm{du} & \text { droit, } & \text { accessed } & \text { September } & 21,\end{array}$ https://www.legifrance.gouv.fr/affichJuriJudi.do?oldAction=rechExpJuriJudi\&idTexte=JURITEXT000007627647\&fastReqId=916795493\& fastPos $=6$.

${ }^{39}$ Cass. Req. 18 janv. 1863, DP 1863, I, p. 248.

${ }^{40}$ Civ. $2^{\mathrm{e}}, 17$ fevr. 1955, JCP G 1955, II, 8951, note R. Rodière.

${ }^{41}$ See Deslauriers-Goulet, C. (2014). Obligation Essentielle dans le Contrat. Cahiers de Droit, 55(4), p 927. Chantepie, G., \& Latina, M. (2016). La réforme du droit des obligations. Commentaire théorique et pratique dans l'ordre du Code civil. Paris, France: Dalloz. P 360.
} 
the characterization of legal relations, or change that characterization. Pothier has explained them stating that these are obligations "without which the contract cannot continue to exist. As without these obligations, it is either that there is no contract at all, or that the matter then concerns a different contract". ${ }^{42}$ For instance, a sales contract that does not include a transfer of ownership is not characterized as a sales contract even if the parties to it describe it as such, as it misses an essential obligation which is the transfer of ownership. Similarly, the case is the same concerning the payment of a due price by a buyer which is considered an essential obligation. Based on this, we find that one of the jurists defined the essential obligation as "the obligation that affects the characterization of the contract, as it is a set of the composing and stable elements of this or that contract which offers it a particular legal characterization". ${ }^{43}$ As such, it seems as if this approach is in agreement with the old French judicial precedents of the French Court of Cassation, in its statement that: "the contract cannot be brought into existence as law unless the obligations that form the essence of the contract have been determined, and a legal relationship/bond is found obliging the contractors with its implementation". ${ }^{4}$

As regards natural obligations (Les Naturalia), these are natural obligations usually found in a particular type of contracts; moreover, their existence in such contracts is supposed even without being explicitly pointed out by the parties, and these are terms that do not influence the qualification of the contract; ${ }^{45}$ for instance, the obligation of the seller to hand over the sold item to the buyer at the place where he is at, at the moment of the contract's conclusion. However, the buyer can require the sold item to be delivered to a different place as, for example, his place of residence or work.

Moreover, as concerns accidental obligations (Les Accidentalia), these are accidental obligations unusually found in a particular kind of contracts, and as such their existence cannot be supposed unless the parties agree on considering them as part of the contract in a clear agreement among them, as this type of terms does not influence the qualification of the contract. ${ }^{46}$

Therefore, it can be said that the essential obligation represents "the hard core of the contract", ${ }^{47}$ and in case of its absence, a contract does not exist, as it does not achieve the purpose underlying it which is represented by the economic transaction which the parties seek to achieve by its conclusion. ${ }^{48}$

As such, the main idea here revolves around the fact that some of the obligations of the debtor are essential obligations, and that the debtor cannot get rid of or avoid his implementation of his obligation when a clause in the contract (for instance, exemption clause or limiting clause of liability) leads to depriving one of the essential obligations of its substance. ${ }^{49}$ For how could the essential obligation of the deliverer in the case of Chronopost of delivering the postal parcel at the specified time according to what has been agreed in the contract be reconciled with requiring him, at the same time, to limit his liability in terms of a trivial sum of money in case his obligation to deliver the postal parcel at the specified time has not been performed, compared to the real damage inflecting the other party as a result of this? Therefore, an obligation on the part of the deliverer to deliver the postal parcel at the specified time cannot be said to exist as long as there is a clause relieving him of this liability or obliges him to pay a trivial compensation in case, he did not perform his obligation. ${ }^{50}$

Consequently, the manifestation of an essential obligation in a particular contract depends primarily on the

\footnotetext{
42 "Les choses qui sont de l'essence du contrat sont celles sans lesquelles ce contrat ne peut subsister, faute de l'une de ces choses, ou il n'y a pas du tout de contrat, ou c'est une autre espèce de contrat". Pothier, R. (1823-1825). Oeuvres de Pothier, Contenant les Traites du Droit Francais. Paris, Bechet Aine. P 6.

43 "l'obligation qui commande la qualification du contrat". Deslauriers-Goulet, C. (2014). Obligation Essentielle dans le Contrat. Supra note, p 929.

44 "qu'un contrat ne peut légalement exister s'il ne renferme les obligations qui sont de son essence et s'il n'en résulte un lien de droit pours contraindre les contractants à les exécuter". See "French Court of Cassation, civil room 2, public sitting of Thursday 25 February 2010, no of appeal: 09-13810," légifrance, le service public de la diffusion du droit, accessed September 22, 2019,

https://www.legifrance.gouv.fr/affichJuriJudi.do?oldAction=rechExpJuriJudi\&idTexte=JURITEXT000021885804\&fastReqId=219292297\& fastPos $=1$.

${ }^{45}$ See Hinestrosa, F. (1998). Des Principes Generaux du Droit aux Principes Generaux des Contrats. Uniform Law Review, 3(2-3), p 515.

${ }^{46}$ Floare, M. (2013). O Privire Istorica Asupra Abordarii Juridice a Bunei Si Relei Credinte in Contracte. Studia Universitatis Babes-Bolyai Jurisprudentia, 2013(4), p 80.

47 Deslauriers-Goulet, C. (2014). Obligation Essentielle dans le Contrat. Supra note, p 950.

${ }^{48}$ See Fokou, E. (2016). La Notion d'Economie du Contrat en Droit Francais et Quebecois. Supra note, p 361.

${ }^{49}$ See Dang Vu, T. (2014). A Belgian Perspective on the Judgments of the French Cour de Cassation of 17 May 2013. European Review of Private Law, 22(2), p 278.

${ }^{50}$ Blanc-Jouvan, X. (2009). Towards the Reform of the Law of Obligations in France: The Reasons for the Reform. Supra note, p 860.
} 
nature of the contract itself and on the collective will of the parties, ${ }^{51}$ as in the case of leasing contracts, for instance, where the obligation of the lessor to hand over the leased property to the lessee to make use of it is considered an essential obligation which the lessor cannot exclude through an opposing clause in the contract and, ${ }^{52}$ as such, the lessee's obligation to pay rent is an essential obligation which the lessee cannot exclude by an opposing clause. ${ }^{53}$

Similarly, the insurer cannot deprive the guarantee from its substance by stipulating a great number of cases of exclusion of the guarantee. ${ }^{54}$ Moreover, in the case of sales contracts, the seller's obligation to deliver a sold item that is valid for the purpose for which the contract has been concluded is considered an essential obligation on his behalf; therefore, he cannot require relieving himself from his liability in case he delivered a sold item that is not valid for use or does not achieve the purpose agreed on in the contract. ${ }^{55}$

In a similar vein, moreover, the obligation of a parking lot owner to keeping the cars and their contents during parking time is considered as an essential obligation on his behalf for which he cannot require exemption through an opposing agreement. ${ }^{56}$ Also, the obligation of a lessor of a refrigerator truck for the delivery of goods cannot require his exemption of liability in case the goods expired owing to a fault in refrigeration, as that contradicts with the essential obligation on his behalf. ${ }^{57}$ Notably, thus, the contract itself might contain more than one essential obligation, as is the case in sales, transfer and leasing contracts.

\subsection{The Clause Depriving the Essential Obligation of the Debtor of its Substance}

Having accurately specified what is considered an essential obligation, we should move on to evaluating the scope of influence of this clause on the essential obligation of the debtor, as Article (1170) of the NFCC does not abolish every clause touching upon an essential obligation of the debtor; however, it considers as not written only the clause depriving the essential obligation of the debtor of its substance.

To illustrate this further, it is found in the report presented to the President of the French Republic concerning this Article that: "contrary to what some of the judicial decisions of the Court of Cassation have been based on, the clause -limiting liability- which concerns the essential obligation of the debtor is not necessarily to be considered as not written: as it is not prohibited unless it contradicts with an essential obligation stated in the contract, depriving that essential obligation (of the debtor) of its substance". ${ }^{58}$ This is the same direction taken by the French Court of Cassation in the case of Faurecia II ${ }^{59}$ as it required the existence of two conditions for the application of the penalty for considering the clause limiting liability as unwritten, and they are: that the clause must concern the essential obligation of the debtor, and that this clause deprives the essential obligation of

51 See Fokou, E. (2016). La Notion d'Economie du Contrat en Droit Francais et Quebecois. Supra note, p 361.

52 "Le bailleur ne peut, par le biais d'une clause relative à l'exécution de travaux, s'affranchir de son obligation de délivrer les lieux loués". See Civ. $3^{\mathrm{e}}, 1^{\mathrm{er}}$ juin 2005, $\mathrm{n}^{\mathrm{o}}$ 04-12200, RTD civ. 2005, 780, obs. J. Mestre et B. Fages.

53 “Justifie légalement sa décision la cour d'appel qui, pour prononcer la résiliation d'un bail et l'expulsion du preneur, relève que s'il n'est pas contestable que les loyers sont quérables et non portables, il n'en demeure pas moins que le locataire, auquel un commandement de payer a été délivré, ne peut arguer d'une éventuelle absence de réclamation antérieure du bailleur pour échapper à son obligation essentielle de s'acquitter effectivement du paiement des loyers”. Civ. $3^{\mathrm{e}}$, 24 nov. 2004, nº 03-15807, RTD civ. 2005, 781, obs. J. Mestre et B. Fages.

${ }^{54}$ Par ex. Com. 13 févr. 2007, JCP 2007, II, 10063, note Serinet ; Defrénois 2007, 1042, obs. Libchaber.

55 See "French Court of Cassation, civil room 1, public sitting of Tuesday 11 October 1966," légifrance, le service public de la diffusion du droit, accessed September 25, 2019,

https://www.legifrance.gouv.fr/affichJuriJudi.do?oldAction=rechExpJuriJudi\&idTexte=JURITEXT000006973521\&fastReqId=946073674\& fastPos=3.

${ }^{56}$ See "French Court of Cassation, civil room 1, public sitting of Wednesday 23 February 1994, no of appeal: 92-11378," légifrance, le service public de la diffusion du droit, accessed 2019, https:/www.legifrance.gouv.fr/affichJuriJudi.do?oldAction=rechExpJuriJudi\&idTexte=JURITEXT000007032038\&fastReqId=485185989\& fastPos=31.

57 “Attendu que, seuls, le dol ou la faute lourde de la partie qui invoque, pour se soustraire à son obligation, une clause d'irresponsabilité insérée au contrat et acceptée par l'autre partie, peuvent faire échec à l'application de ladite clause". See "French Court of Cassation, commercial room, public sitting of Monday 15 June 1959, no of appeal: 57-12362," légifrance, le service public de la diffusion du droit, accessed September 26, 2019, https:/www.legifrance.gouv.fr/affichJuriJudi.do?oldAction=rechExpJuriJudi\&idTexte=JURITEXT000006952917\&fastReqId=2010387963 $\&$ fastPos $=1$.

58 “Contrairement à ce qu'avaient pu retenir certaines décisions de la cour de cassation, une clause limitative de responsabilité portant sur une obligation essentielle du débiteur ne sera pas nécessairement réputée non écrite : elle n'est prohibée que si elle contredit la portée de l'engagement souscrit, en vidant de sa substance cette obligation essentielle". Rapport au Président de la République relatif à l'ordonnance no 2016-131 du 10 février 2016 portant réforme du droit des contrats, du régime général et de la preuve des obligations, JORF no 0035 du 11 février 2016, texte no 25.

59 See footnote no: 25 . 
the debtor of its substance.

However, the question that comes to mind instantly is: how does the clause deprive the essential obligation of the debtor of its substance?

Article 1170 of the NFCC did not provide an answer to this question. Therefore, the jurisprudence attempted to determine that (depriving the essential obligation of its substance) based on two rules: the first depends on an overall estimation of the clause in view of the other clauses of the contract, while the second depends on an objective estimation of the clause to determine the extent to which the clause has deprived the essential obligation of the debtor of its substance.

\section{Firstly: The Overall Estimation of the Clause}

In application of the previous Article and following in the footsteps of the previous judicial precedents, most of the French jurisprudence believe that the judge, while evaluating the manner in which the clause deprives the essential obligation of the debtor of its substance, should depend on the overall evaluation of all of the contract's clauses, and not only on the clause being the subject of disagreement. ${ }^{60}$ For, in some cases, if only the clause itself has been evaluated alone, it may be considered unwritten as it deprives the essential obligation of the debtor of its substance, but if this clause has been evaluated along with a consideration of all of the contract's clauses, it might be balanced and thus does not deprive the essential obligation of the debtor of its substance, which means keeping this clause as included in the contract.

In this regard, one of the jurists states that: "with respect to contractual equilibrium, the supervision used by the text does not only include the corresponding obligations, rather it also includes all of the elements that together form the content of the contract. In more accurate terms, when each corresponding obligation forms an essential obligation, then supervision of their balance is indirect -balancing them is not to be depended on- rather, it is done in accordance with the other clauses included in the contract" ${ }^{61}$

It appears clearly that this opinion takes the direction that has been consolidated by the Commercial Room of the French Court of Cassation in the case of Faurecia II, when it ruled that: "only the clause limiting liability which contradicts with the essential obligation of the debtor is considered unwritten," as such, the court, in this case, did not consider as unwritten the clause limiting liability as "it did not deprive the essential obligation of the debtor of its substance completely," as the clause seemed to contradict the essential obligation of the debtor if it has not been evaluated alone, but it does not deprive the essential obligation of the debtor of its substance if it has not been evaluated while considering the remaining clauses of the contract. ${ }^{62}$

Based on this, it appears that the Court of Cassation estimated the clause in this case in concreto by estimating the clause within its general context; meaning, while looking at the overall contract, as other obligations might exist in the contract, which may lead to restoring equilibrium to the clause limiting liability; consequently, it does not lead to depriving the essential obligation of the debtor of its substance. Thus, the judge must prevent the debtor from holding on to the clause that seems to be depriving his essential obligation completely of its substance, and must look for the existence of other clauses in the contract leading to its equilibrium. ${ }^{63}$

\footnotetext{
${ }^{60}$ See Pillet, G. (2016). The Reform of French Contract Law and of the General Rules on Obligations: The Civil Code Faces the Challenges of the Market. Supra note, p 246.

${ }^{61}$ A.-S. Courdier-Cuisinier, «L'équilibre contractuel ab initio », in Analyse comparée du droit français réformé des contrats et des règles matérielles du commerce internationale, C. Jourdain-Fortier et M. Mignot, LexisNexis, vol. 47, 2016, p. 173, spéc. 192 : "Du point du vue de l'équilibre contractuelle, le contrôle mis en place ne porte alors pas seulement sur les prestations réciproques mais sur tous les éléments du contenu contractuel. Plus, exactement quand les prestations réciproques sont chacune l'objet d'une obligation essentielle, le contrôle de leur équilibre n'est qu'indirect - il ne résulte pas de leur mise en balance - puisqu'il s'opère à partir des autres clauses du contrat".

${ }^{62}$ See footnote no: 27.

${ }^{63}$ E. Mouial Bassilana, « Abus de dépendance et clauses abusives », in La réforme du droit des contrats en pratique, sous dir. M. Latina, éd. Dalloz, 2017, p. 51, spec. $n^{\circ} 14$, p. 59.

Although most French jurisprudence supports the overall estimation of the clause, some still question the French Court of Cassation's adoption of the overall estimation from now on, based on Article 1170 of the Civil Code, where they see that:

« A suivre une interprétation exégétique du texte, il n’y aurait plus à étudier la cohérence générale du contrat, de sorte qu'il n'est pas certain qu'avec cette nouvelle disposition, on puisse encore mettre en avant l'environnement contractuel et les éventuelles contreparties accordées en échange de la stipulation. Est-ce bien le but que poursuivait le rédacteur du texte ? on peut en douter de sorte que l'on continuera de conseiller aux parties de justifier, dans leur contrat, les clauses qui prima facie, semblent déséquilibrées », Th. Douville (dir) et autres, «La réforme du droit des contrats, commentaire article par article, ordonnance du 10 février 2016 portant réforme du droit des contrats, du régime général et de la preuve des obligations »,in éd. Gualino 2016, p. 138.
} 


\section{Secondly: The Objective Estimation of the Clause}

To evaluate the extent of the clause's depriving of the essential obligation of the debtor of its substance, most of the French jurisprudence think that doing that should adhere to an objective standard, that depends on the substance of the contract and its general financial equilibrium, ${ }^{64}$ and its economic results, ${ }^{65}$ and not on the capacity or satisfaction of the parties. Based on this standard, the clause can be considered as depriving the essential obligation of the debtor of its substance when it leads to exempting the debtor of an essential obligation on his part or to reducing the essential obligation of the debtor to an extent that makes such an obligation almost non-existent. ${ }^{66}$ In such cases, the clause abolishes the essential performance which is the subject of the debtor's obligation and, at the same time, deprives the corresponding obligation of the other party from its substance, too.

However, this is the same direction taken by Article 7.1.6 of the PICC, according to the interpretation of which, the clause (exemption or limiting liability clause) is in itself unfair when its application leads to a clear disequilibrium between the obligations of the parties. ${ }^{67}$ This, as such, also agrees with the direction of Article (109:8) from the European Principles of contract's law which point to the clauses that oblige the debtor to perform his obligation and, at the same time, exempts him from any penalty in case of non-performance. ${ }^{68}$

As such, two observations concerning the objective standard could be introduced:

The First Observation: the previous text, and according to this objective standard, came to face the grave imbalance between the obligations of the parties resulting from the clause that is the subject of disagreement and not as a general rule to face the imbalance between the rights and obligations of the parties no matter how slight. This could be understood from the perspective that the penalty for considering the clause as unwritten is not applied unless it is the clause that "deprives the essential obligation of the debtor of its substance", while other cases of imbalance can be processed through other legal texts.

It could also be understood from a different perspective that Article (1170) came as an alternative to the theory of causation; in this regard, one of the French jurists states that: "the judgments of Article 1170 have been adopted as an alternative to the theory of causation, according to which, the contract must achieve the least amount of benefit for each contracting party, which is what justifies the existence of the contract (i.e., its cause). Therefore, the clauses that must be abolished according to Article 1170 are only the clauses that directly contradict the essential benefit behind the contract.

Moreover, this has also been the logic on which the judicial precedents in the cases of Chronopost and Faurecia II were based: ${ }^{69}$ (as it is considered "only unwritten . . ." according to the last decision) the clause that contradicts the obligation that represents the core of the contract and, in consequence, must be abolished, as keeping it prevents the creditor from actually achieving anything. It is here that we understand why reference has been made to "the essential obligation" of the debtor. This also is the reason too for the necessity of keeping the clause that deprives a minor/secondary obligation of its substance, as it does not participate in contributing to the fundamental benefit behind the contract". ${ }^{70}$

\footnotetext{
${ }^{64}$ A.-S. Courdier-Cuisinier, «L'équilibre contractuel ab initio », in Analyse comparée du droit français réformé des contrats et des règles matérielles du commerce internationale, C. Jourdain-Fortier et M. Mignot, LexisNexis, vol. 47, 2016, p. 173, spéc. 193.

${ }^{65}$ See Chantepie, G., \& Latina, M. (2016). La réforme du droit des obligations. Commentaire théorique et pratique dans l'ordre du Code civil. Supra note, $\mathrm{p} 361$. Before enacting Article 1170 of the NFCC, a side of French jurisprudence believed that the estimation of the existence of the cause is based on an objective criterion based on the economics of the contract "économie du contrat", where the absence of the cause is not achieved only when there is no financial counterpart for the commitment of one of the parties, but also in the case of the absence of benefit that the contracting party wants to get from the contract. On this topic, see generally: S. Pimont, "L'économie du contrat ", th. PUAM 2004 ; A. Zellevic-Duhamel, « La notion d'économie du contrat », JCP G 2001, I, 300 ; J. Moury, « Une embarrassante notion : L'économie du contrat », D 2000, chron. 382.

${ }^{66}$ Chantepie, G., \& Latina, M. (2016). La réforme du droit des obligations. Commentaire théorique et pratique dans l'ordre du Code civil. Supra note, p 361 .

${ }^{67}$ See footnote no: 15 .

${ }^{68}$ See footnote no: 17 .

${ }^{69}$ See pages 4-7.

70 "conçus comme des substituts de la cause, entendent que le contrat présente une utilité minimale pour chaque contractant, celle-là même qui constitue la raison d'être de l'engagement (sa cause). Les clauses qui doivent être éradiquées en application de l'article 1170 sont donc celles-là seulement qui s'opposent frontalement à ce que le contrat déploie son utilité fondamentale : celles qui le vident de sa cause. Tel était du reste le raisonnement qui portait les jurisprudences Chronopost et Faurecia II : c'est seulement ("Seule est réputée non écrite... » énonçait ce dernier arrêt) lorsqu'une clause a pour effet de contredire l'engagement qui fait le cœur du contrat qu'elle doit être mise à l'écart. Car en sa présence, le créancier n'obtient rien de réel. Ainsi faut-il comprendre la référence à « l'obligation essentielle » du débiteur. Et c'est aussi la raison pour laquelle la clause qui priverait de sa substance une obligation accessoire - qui ne participe pas de l'utilité fondamentale
} 
Moreover, the same jurist states that: "it is not enough that the clause creates an influencing imbalance between the rights and obligations of the parties to the contract according to Article 1171 of the NFCC which considers as unwritten the clause that creates an influencing imbalance between the rights and obligations of the parties in contracts of adhesion, this (influencing imbalance) is not alone enough to make the clause deprive the essential obligation of the debtor of its substance. ${ }^{71}$ As such, misusing Article 1170 as a tool for reformulating the contract is unacceptable, as the parties must remain free in writing the contract in the way they deem suitable, even if it becomes objectively unbalanced.

Therefore, for the application of Article 1170 in the future, it is necessary to distinguish between: the clauses that are unforgivable as they pose a violation even of the binding force of the contract to a degree which makes the obligation of one party purely dependent on its will, and these (the clauses) are governed by Article 1170; and the clauses that, without having the same effect, distort the generally expected benefit of the contract and, in this case then, Article 1171 is applied within the field specified for its application (contracts of adhesion)". ${ }^{72}$

The Second Observation: this assessment, according to the objective standard, depends on the extent of the clause's depriving of the essential obligation of the debtor of its substance, which requires the judge to estimate the real impact of the clause on the essential obligation of the debtor, and the extent of its depriving of this obligation of its substance, ${ }^{73}$ through the judge's observation of the benefit behind the contract and the economic utility it seeks to achieve. ${ }^{74}$ Furthermore, the judge should not depend, in this evaluation, on the behaviour of the debtor himself and the extent of the danger posed by this behaviour, contrary to the exclusion of the clause limiting liability that is based on cheating and the serious error of the debtor, which is estimated in accordance with a personal standard based on the extent of the danger of the debtor's behaviour by non-performance of his obligation. ${ }^{75}$ In this regard, the French Court of Cassation stated in the case of Faurecia II: "Serious error cannot only be the result of violating the obligation, even if it was essential; however, it should also be based on the dangerous behaviour of the debtor". ${ }^{76}$

Based on what has been stated above, the application of Article 1170 requires, for considering the clause as unwritten, the materialization of two things: 1) that the clause should pose a violation of the core of the contract; 2) that this violation of the core of the contract should be grave as to deprive the contract of its real substance or the actual benefit behind it, justifying the execution of penalty for considering the clause as unwritten. ${ }^{77}$

\section{The Penalty for Considering the Clause as Unwritten}

While investigating the contract for the existence of a clause that deprives the essential obligation of the debtor of its substance, then the penalty implied by Article 1170 of the NFCC for that is the consideration of the clause as "unwritten"; meaning, considering the clause as non-existent, or as if it has never been included in the contract. ${ }^{78}$ Here, it should be noted that the penalty included in this article is the same penalty which has been consolidated by past French judicial precedents within this context, especially in the cases of Chronopost and Faurecia II. ${ }^{79}$ Based on this, the clause that is the subject of disagreement is what gets to be considered as

de l'accord - devra être maintenue ». See Deshayes, O., Genicon, T., \& Laithier, Y. M. (2016). Réforme du droit des contrats, du régime général et de la preuve des obligations: commentaire article par article. Supra note, $\mathrm{p}$ 294-295.

${ }^{71}$ See footnote no: 12 .

${ }^{72}$ See Deshayes, O., Genicon, T., \& Laithier, Y. M. (2016). Réforme du droit des contrats, du régime général et de la preuve des obligations: commentaire article par article. Supra note, p 296-297.

${ }^{73}$ See Chantepie, G., \& Latina, M. (2016). La réforme du droit des obligations. Commentaire théorique et pratique dans l'ordre du Code civil. Supra note, p 362 .

${ }^{74}$ Ibid., p 361 .

${ }^{75}$ M. Fabre-Magnan, précité, $n^{\circ} 727$, p. 784.

76 “que, surabondamment, la faute lourde, qui ne peut résulter du seul manquement à une obligation, fût-elle essentielle, mais doit se déduire de la gravité du comportement du débiteur". See "French Court of Cassation, civil room 3, public sitting of Thursday 23 May 2013, no of appeal: 12-11652," légifrance, le service public de la diffusion du droit, accessed September 27, 2019,

https://www.legifrance.gouv.fr/affichJuriJudi.do?oldAction=rechExpJuriJudi\&idTexte=JURITEXT000027452639\&fastReqId=1286638816 $\&$ fastPos $=2$.

${ }^{77}$ See Deshayes, O., Genicon, T., \& Laithier, Y. M. (2016). Réforme du droit des contrats, du régime général et de la preuve des obligations: commentaire article par article. Supra note, p 294-295.

${ }^{78}$ See S. Gaudemet, "La clause réputée non écrite », préf. Y. Lequette, Economica 2010; Cottereau, « La clause réputée non écrite », JCP 1993, I, 3691; J. Kullman, « Remarques sur clauses réputées non écrites », D. 1993, chron. 59; R. Billod, « A propos des clauses réputées non écrites », in Mélanges Louis Boyer, PUSS, Toulouse, 1996.

${ }^{79}$ See Gheorghe, O. (2018). Theoretical Considerations and Practical Aspects on the Institution of Guilt within the Contractual Liability and the Limitation of the Contractual Liability. Supra note, $\mathrm{p} 47$. 
non-existent, while other clauses of the contract remain valid as they have been, without any modifications or replacements.

Moreover, it may seem as if the application of penalty for considering the clause alone as unwritten in this case is far-fetched, as the matter concerns an essential clause in the contract and not a secondary one where its existence in the contract leads to depriving the essential obligation of the debtor of its substance; then, the penalty that should be applied in this case is declaring the contract as invalid either completely or partly, and not just abolishing one of its clauses. ${ }^{80}$ This type of analysis is confirmed by the fact that Article 1170 came, with the agreement of the jurisprudence, as an application of the theory of causation which has been abolished by the French Decree of 2016, and as a consolidation of the past French judicial precedents in this regard; as such, the penalty for the absence of cause is the complete invalidity of the contract and not only one of its fundamental clauses.

Furthermore, some justify the penalty for considering the clause as unwritten and not the invalidity of the contract on the basis that the penalty decided by the French Court of Cassation in the case of Chronopost is not the absence of the cause leading to the invalidity of the contract -represented by the customer's commitment to paying the price for the services he receives; rather, it is the abolishing of the clause that deprives the essential obligation of the deliverer of its substance and considering it as unwritten to oblige the deliverer to compensate the customer according to the general rules of contractual liability. ${ }^{81}$

Consequently, based on the above analysis, it becomes clear that the French legislature, while applying the penalty for considering the obligation -essential- as unwritten as in Article 1170, aims to keep the contract valid for the parties while restoring equilibrium to it to the extent necessary, where it becomes satisfactory for both of the parties, achieving the benefit sought by each one of them, ${ }^{82}$ by abolishing the only clause that leads to imbalance in the contract. For instance, abolishing the exemption clause or the one limiting liability that deprives the essential obligation of the debtor of its substance requires going back to the general rules concerning contractual liability.

However, regardless of the purpose which the French legislature aims to achieve in Article 1170, which is keeping the contract and restoring equilibrium between the obligations of the parties, it remains that the consolidation of an individual penalty which is the consideration of the clause as unwritten as the only penalty in all cases and circumstances could be severely criticised in some cases. The penalty of considering the clause as unwritten might be justifiable and suitable if the clause itself is the one leading to depriving the obligation of the debtor of its substance, where abolishing the clause itself is the only means to restore balance to the contract. ${ }^{83}$ However, in other cases, when imbalance is attributable not to the clause itself, but -rather- to its substance, then it could be best to revise the content of the clause as to restore balance to the contract, as abolishing the clause -on the contrary- might lead to further imbalance in the contract; therefore, allowing the revision of the content of the clause in some cases leads to avoiding the creation of a new imbalance in the contract and, at the same time, maintains the financial balance of the contract leading, thus, to legal stability. ${ }^{84}$

Whichever may be the case, as long as the legislature's purpose behind this text is to restore balance to the contract by considering the clause alone as unwritten and guaranteeing the efficiency of this penalty, it is prohibited for the debtor to hold on to the belief that this clause has had an essential and decisive influence on him accepting the conclusion of the contract, in an attempt on his part to terminate the contract as this would allow the creditor to avoid having to implement the contract -while the purpose of the text is to maintain the

\footnotetext{
80 "Une telle sanction "le réputé non écrit", ait pu être critiqué, en ce qu'elle aurait été « difficilement compatible avec un manquement à une obligation jugée essentielle par la cour de cassation: un tel manquement devrait nécessairement entrainer, parce qu'il porte sur l'essence même du contrat, sa nullité intégrale”. D. Cohen, note sous Com. 22 oct. 1996, JCP 1997, II, 22881.

${ }^{81}$ See M. Fabre-Magnan, Droit des obligations, 1-Contrat et engagement unilatéral, $4^{\mathrm{e} e ́ d . ~ P U F, ~ j u i l l . ~ 2016, ~ n º ~ 414, ~ p . ~} 450$.

${ }^{82}$ See Chantepie, G., \& Latina, M. (2016). La réforme du droit des obligations. Commentaire théorique et pratique dans l'ordre du Code civil. Supra note, p 362.

${ }^{83}$ A.-S. Courdier-Cuisinier, "L'équilibre contractuel ab initio », in Analyse comparée du droit français réformé des contrats et des règles matérielles du commerce internationale, C. Jourdain-Fortier et M. Mignot, LexisNexis, vol. 47, 2016, p. 173, spéc. 192.

84 "L'article 1170 entend permettre le redressement judiciaire du contrat pour le remettre dans son axe fondamental. C'est donc une réécriture de l'accord qu'il s'agit, dans l'intérêt du créancier pour qu'il ne se trouve pas privé du contrat. C'est là tout le risque que présente la procédé et une bonne raison pour le tenir dans des limites étroites". See Deshayes, O., Genicon, T., \& Laithier, Y. M. (2016). Réforme du droit des contrats, du régime général et de la preuve des obligations: commentaire article par article. Supra note, p 295.
} 
benefit of the debtor by keeping the contract with the exclusion of the clause being the subject of disagreement. ${ }^{85}$ It is also notable that the application of the penalty for considering the clause as unwritten does not require resort to the judiciary, as the clause leading to depriving the essential obligation of the debtor of its substance is in existence ever since it is included in the contract and, as such, precedes the judicial suit. Moreover, even if there has been no resort to the judiciary, the decision of the court in this case is declaratory and not constitutive, as the role of the judge is a limited one - declaring the clause as unwritten. As such, as long as the decision of the court is declaratory, then the penalty for considering the clause as unwritten is not subject to prescription. Nonetheless, in all cases, the judge, examining the conflict, can consider the clause as unwritten in accordance with Article 1170 on his own initiative without being requested to do so by one the parties.

\section{Conclusion}

Finally, we have been able to arrive at the following results:

- The text of Article 1170 of the NFCC came as a codification of the most important contemporary judicial applications of the theory of causation, and as an alternative to abolishing this theory based on the Decree of 2016. However, unlike the past judicial precedents that limited the scope of its application through the clauses of exemption and limiting of liability, the new text covers all clauses of the contract irrespective of the nature of these clauses and the nature of the relevant contracts whether they are negotiation contracts or contracts of adhesion. However, nonetheless, the scope of application of the new text is limited to abolishing the clauses that deprive the essential obligation of the debtor of its substance, and therefore is not a general rule to restore balance to contracts in general, as this is dealt with by other legal texts.

- Specifying what is meant by the concept of the "essential obligation", no matter how difficult it could be; nonetheless, with the consensus of the French jurisprudence, should be based on the nature of the contract and its substance and the collective will of the parties, as represented by the obligations that participate mutually in achieving the intended purpose of the parties by concluding the contract. However, the clauses that influence such essential obligations are the only ones that can be deemed unwritten as long as they lead to depriving the essential obligation of the debtor of its substance, while other clauses (secondary ones or those that do not lead to achieving the purpose) are not included in the application of the previous text and the penalty it requires.

- Depending on the overall evaluation of the clause with a view to the other clauses of the contract and, as well, depending on the objective evaluation of the clause based on the general financial balance of the contract to evaluate the extent of the clause's depriving of the essential obligation of the debtor of its substance leads to achieving the purpose sought by the legislature in consolidating the previous text, which is represented by restoring balance to the contract in specific cases when imbalance is grave. As such, this can, on the one hand, limit the authority of the judge as not to exaggerate the use of this text in restoring balance to the contract, which reduces the number of cases where contractual clauses are abolished and, on the other, maintains the freedom of the parties in including whatever clauses they deem as suitable in their contracts and not to limit this freedom except in cases where a clause leads to a grave violation of the economic aspects of the contract and the benefit sought by its conclusion.

- Instituting the penalty for considering the clause as unwritten, when it deprives the essential obligation of the debtor of its substance, aims to maintain the contract with the exclusion of the clause being the subject of disagreement. However, this penalty may not be suitable in other cases, when it is the content of the clause and not the clause itself that deprives the essential obligation of the debtor of its substance. Therefore, the best means has been to offer the judge the authority to revise this specific clause, and not to abolish it, restoring -thus- the contract back to its normal state of balance.

\section{References}

(2017). Limitation and Exclusion clauses in CISG Contracts. Nordic Journal of Commercial Law, (2), 232-315.

Alexe, A. (2017). Clauses Deemed Unwritten. International Landmarks. Research and Science Today, 13(Supplement 1), 22-29.

Asfar-Cazenave, C. (2015). The New French Contract Law. Revue Juridique Themis, 49(3), 717-756.

Blanc-Jouvan, X. (2009). Towards the Reform of the Law of Obligations in France: The reasons for the Reform. Tulane Law Review, 83(4), 853-876.

\footnotetext{
85 "le texte interdit donc au créancier d'arguer du caractère déterminant, pour son engagement, de la clause litigeuse afin de réclamer la chute du contrat en son entier. Cela se comprend bien: ce serait lui permettre de s'en sortir à trop bon compte là où l'on entend préserver l'intérêt du débiteur au maintien d'un contrat expurgé du dispositif qui l'entravait". See Ibid., p 298.
} 
Borello, M. (1984). Conformité, Garantie et Clauses élisives ou Limitatives de Responsabilité dans le Droit Anglais de la Vente. Revue internationale de droit comparé, 36(2), 373-388. https://doi.org/10.3406/ridc.1984.1614

Chantepie, G., \& Latina, M. (2016). La réforme du droit des obligations. Commentaire théorique et pratique dans l'ordre du Code civil. Paris, France: Dalloz.

Chappuis, C. (2008). Le Renoncement la Cause et la Consideration dans l'avant-Projet d'acte Unifrome Ohada sur le Droit des Contrats. Uniform Law Review, 13(Issues and 2), 253-292. https://doi.org/10.1093/ulr/13.1-2.253

Chénedé, F. (2016). Le nouveau droit des obligations et des contrats: consolidations, innovations, perspectives. Paris, France: Dalloz.

Dang Vu, T. (2014). A Belgian Perspective on the Judgments of the French Cour de Cassation of 17 May 2013. European Review of Private Law, 22(2), 261-282.

Deshayes, O., Genicon, T., \& Laithier, Y. M. (2016). Réforme du droit des contrats, du régime général et de la preuve des obligations: commentaire article par article. LexisNexis.

Deslauriers-Goulet, C. (2014). Obligation Essentielle dans le Contrat. Cahiers de Droit, 55(4), 923-950. https://doi.org/10.7202/1027854ar

Faria, J. (2016). The Influence of the Unidroit Principles of International Commercial Contracts on National Laws. Uniform Law Review, 21(2-3), 238-270. https://doi.org/10.1093/ulr/unw013

Floare, M. (2013). O Privire Istorica Asupra Abordarii Juridice a Bunei Si Relei Credinte in Contracte. Studia Universitatis Babes-Bolyai Jurisprudentia, (4), 72-100.

Fokou, E. (2016). La Notion d'Economie du Contrat en Droit Francais et Quebecois. Revue Generale de Droit, 46(2), 343-378. https://doi.org/10.7202/1038621ar

Ganilsy, M., \& Wachtel, R. (2012). Civil Liability under French Law and PCI DSS. International Business Law Journal, (1), 122-128.

Gheorghe, O. (2018). Theoretical Considerations and Practical Aspects on the Institution of Guilt within the Contractual Liability and the Limitation of the Contractual Liability. Journal of Law and Public Administration, 4(7), 43-49.

Ghozlan, S. (2015). The Concept of Essential Obligation Under the Control of Abusive Clauses: The Study of French and Quebec Legal Systems. Revue Juridique Themis, 49(2), 399-450.

Hinestrosa, F. (1998). Des Principes Generaux du Droit aux Principes Generaux des Contrats. Uniform Law Review, 3(2-3), 501-518. https://doi.org/10.1093/ulr/3.2-3.501

Le Coq, J. (2017). The Stakes and Objectives of the Reform of Contract Law, General Regime and Proof of Obligations. International Business Law Journal, 2017(6), 515-532.

Mato Pacin, M. (2015). Content Control of Standard Terms in Business-to-Business Contracts in Comparative and European Law. Cuadernos de Derecho Transnacional, 7(2), 216-282.

Mekki, M. (2017). The French Reform of Contract Law: The Art of Redoing Without Undoing. Journal of Civil Law Studies, 10(1), 223-260.

Pillet, G. (2016). The Reform of French Contract Law and of the General Rules on Obligations: The Civil Code Faces the Challenges of the Market. International Business Law Journal, 2016(3), 235-254.

Pop, L. (2018). General Considerations on the Reform of the Right of Obligations in the French Civil Code. Romanian Review of Private Law, 2018(1), 273-289.

Pothier, R. (1823-1825). Oeuvres de Pothier, Contenant les Traites du Droit Francais. Paris, Bechet Aine.

Principles of European Contract Law.

Rawach, E. (2001). La Validité des Clauses Exonératoires de Responsabilité et la Convention de Vienne sur la Vente Internationale de Marchandises. Revue internationale de droit comparé, 53(1), 141-157. https://doi.org/10.3406/ridc.2001.18015

Rowan, S. (2017). The New French Law of Contract. International and Comparative Law Quarterly, 66(4), 805-832. https://doi.org/10.1017/S0020589317000252

Schmidt, J. (2002). Les Lettres D'intention. International Business Law Journal, 2002(Issues \& 4), 257-270. 
The New French Civil Code, which was created by Decree N 131-2016 of 10 February 2016.

UNIDROIT Principles of International Commercial Contracts.

Valentino, D. (2016). Software Assistance and Maintenance Contracts. European Business Law Review, 27(4), 535-554.

Woker, T. (1999). The Right of an Employer to Exempt Himself or Herself from Liability for the Deliberate Wrongs of His or Her Employee. South African Law Journal, 116(4), 722-729.

\section{Copyrights}

Copyright for this article is retained by the author(s), with first publication rights granted to the journal.

This is an open-access article distributed under the terms and conditions of the Creative Commons Attribution license (http://creativecommons.org/licenses/by/4.0/). 